\title{
OBSTRUCTIVE SLEEP APNEA AND INSULIN RESISTANCE: A ROLE FOR MICROCIRCULATION?
}

\author{
Nicolas Wiernsperger, Pierre Nivoit, and Eliete Bouskela
}

\begin{abstract}
Wiernsperger N, Nivoit P, Bouskela E. Obstructive sleep apnea and insulin resistance: a role for microcirculation? Clinics. 2006;61(3):253-66.
\end{abstract}

Obstructive sleep apnea is an increasingly recognized medical problem. The recent attention to its frequency in the general population and its important role in metabolic, vascular, and behavioral aspects have sharply increased the number and nature of investigations, thereby revealing new aspects that open new approaches in research. Whereas obstructive sleep apnea is a wellknown phenomenon accompanying obesity and diabetes, new findings strongly suggest that this close relationship may also operate in the opposite direction. Indeed obstructive sleep apnea may be a primary feature inducing or aggravating a series of vascular and metabolic disturbances closely resembling the metabolic syndrome. This review will discuss established and potential mechanisms responsible for these changes. Obstructive sleep apnea indeed appears to gather all the elements necessary to induce insulin resistance, hypertension, and possibly heart failure. After careful analysis of these modifications and considering how they are intertwined, we propose that microcirculation could represent the common denominator mediating the progression of this pathology, as it is eventually the case in the metabolic syndrome and diabetes domain. This plausible hypothesis is discussed in detail and should be verified by appropriate preclinical and clinical protocols, which are now achievable by using noninvasive techniques in humans.

KEYWORDS: Obstructive sleep apnea. Insulin resistance. Hypoxia. Metabolic syndrome. Microcirculation.

\section{INTRODUCTION}

Few domains of medicine have experienced so much interest as obstructive sleep apnea (OSA) over the last 10 years. The sharp rising interest in this phenomenon started when it was first suggested that OSA may not just be an accompanying symptom but might cause or aggravate metabolic and vascular diseases.

Sleep disordered breathing comprises several processes that provoke repetitive interruptions in sleep, mainly due to snoring and hypopneas/apneas of either central or OSA origin. Epidemiologically, the OSA syndrome affects probably about $5 \%$ of the general population. The prevalence of OSA is much higher in diseases as common as hyper-

Department of Physiological Sciences, State University of Rio de Janeiro Rio de Janeiro/RJ, Brazil.

Email: eliete_bouskela@yahoo.com.br

Received for publication on January 19, 2006.

Accepted for publication on April 10, 2006. tension $(22-48 \%)^{1}$ or heart failure $(11-37 \%)$. In this latter group, central apneas are seen in $45 \%$ of subjects ${ }^{2}$ and are inversely related to cardiac ejection fraction. Half of the patients with diastolic heart failure have an increase in the number of apneas.

The present review will describe the most recent knowledge about links between obstructive sleep apnea and cardiometabolic disorders. In particular, the possibility that this relationship operates in both directions is a recent view that strongly stimulates interest in new preclinical and clinical research. We will also discuss the plausible hypothesis that the microcirculation may be the common denominator of these intertwined disturbances.

\section{OSA IS A SERIOUS CLINICAL CONDITION}

Apneas are either complete or incomplete (hypopneas), which has led to the creation of a so-called apnea/hypopnea index (AHI) that permits the evaluation of frequency of 
apneas in patients. Obstructive sleep apneas are of mechanical origin, due to the failure of upper airways to maintain their muscle tone. Not surprisingly OSAs are most frequent in obese individuals, as a consequence of fat deposition in the muscles of the upper airways. Almost all OSA subjects exhibit intense snoring, but snoring is not necessarily accompanied by OSA. This is important in clinical trials, which partly were based on this indirect parameter. The link between OSAs and obesity is strong, such as to bias many protocols and interpretations of older clinical studies. A $10 \%$ increase in body weight over 4 years increases the risk for OSA 6-fold. ${ }^{3}$ Recent findings revealed that half of the genetic variance in OSA is shared with obesity phenotypes, ${ }^{4}$ which may have important consequences, as will be discussed later. Obstructive sleep apneas are more frequent during REM sleep, ${ }^{5}$ and their number, usually of short duration (around $20 \mathrm{~s}$ ) can reach several hundred per night. Sleep apneas up to 1 min can be found, a situation that may be life-threatening. Each sleep apnea is characterized by hypoxia during breathlessness, with blood oxygen saturation $\left(\mathrm{SaO}_{2}\right)$ down to $50 \%$ in extreme cases. The degree of desaturation is at least as important as the total number of episodes for complications linked with OSA. Each episode is followed by an arousal reaction restoring breath, thereby inducing abrupt reoxygenation. Patients with OSA suffer daytime sleepiness, a situation closely linked to car accidents, especially in the late afternoon.

\section{OSA and Insulin Resistance / Glucose Tolerance / Diabetes}

There is a very close link between insulin resistance (IR) and OSA, but causative mechanisms are disputed. ${ }^{6,7}$ It was well-known that snoring and OSA are essentially seen in overweight/obese patients characterized by IR or the metabolic syndrome; more recent investigations support this link by showing that other diseases characterized by IR are also linked with OSA: in patients with polycystic ovary syndrome, elevated insulin levels and impaired glucose tolerance correlated with a higher frequency of OSAs, and this correlation was even independent of BMI in glucose normotolerant women. ${ }^{89}$ Similarly, OSA affects about two thirds of acromegalic patients. ${ }^{10,11}$ Nonalcoholic steatohepatitis (NASH), a situation found in most IR-patients, is also linked to severe OSA, with patients having high AHI values being more insulin-resistant and exhibiting more steatosis as well as elevated liver enzymes. ${ }^{12}$ Illustrating the close relationship between IR and obstructive sleep apnea, it was proposed that OSA should be added to syndrome $\mathrm{X}$ (metabolic syndrome) and the new entity be called syndrome Z. ${ }^{13} \mathrm{~A}$ main question is still whether this correlation is simply due to-or is independent ofexcess fat (BMI or visceral fat). Table 1 shows how OSA superimposed on obesity worsens various metabolic and vascular parameters.

Table 1 - Additional effects of obstructive sleep apnea (OSA) on metabolic and vascular parameters in obesity. Data on control (healthy) subjects and obese patients without OSA are also shown (adapted from ref. 6)

\begin{tabular}{lccc}
\hline & $\mathrm{C}$ & $\mathrm{Ob}$ & $\mathrm{Ob}+$ OSA \\
\hline BMI & 26 & 36 & 38 \\
MABP & 92 & 102 & 107 \\
Visceral fat area & & 220 & $337^{*}$ \\
Total wake time & 66 & 59 & 113 \\
REM latency & 74 & 82 & 93 \\
Minimum $\mathrm{O}_{2}$ saturation & 94 & 91 & 74 \\
\hline
\end{tabular}

Indeed, several studies have claimed the correlation to be strictly due to the presence or absence of concomitant obesity in children ${ }^{14}$ and adults. ${ }^{15}$ In contrast, more recent studies suggest that whereas obesity plays a role, elevated AHI and minimum $\mathrm{SaO}_{2}$ values are important determinants of impaired glucose tolerance. ${ }^{16}$ In these patients, each additional apneic episode increased plasma insulin and the HOMA-index by $0.5 \%$. In another study, the degree of glucose intolerance was related to the severity of desaturation. It was estimated that each $4 \%$ drop in $\mathrm{SaO}_{2}$ represented an odds ratio of 1.99 for glucose intolerance. ${ }^{17}$ Independently of BMI, fasting insulin-an indirect indicator of IR-correlated with OSA severity. ${ }^{18}$

However, here again, a bias in interpreting such data lies in the fact that a sleep debt per se, such as frequently interrupted sleep or shortened sleep duration without breathing abnormalities, also leads to IR. ${ }^{19}$ Indeed, patients submitted to sleep debt exhibit a higher HOMA index, abnormal glucose tolerance, and a reduction in first-phase insulin secretion. ${ }^{20}$ Therefore, some of the mechanisms involved might also be due to sleep deprivation rather than strictly hypoxia/reoxygenation. In the recent Sleep Heart Health Study, the odds ratio for fasting glucose intolerance was 1.7 for mild and 1.46 for severe OSA, and this correlated with $\mathrm{SaO}_{2}$. In this large-scale clinical investigation, OSA was independently associated with glucose intolerance, IR, and noninsulin-dependent diabetes mellitus. ${ }^{21}$ In another trial, fasting and postload glycemia increased with OSA severity, with a concomitant decrease in insulin sensitivity. ${ }^{22}$ Recently, it was shown that a high fat diet in normal rats was followed by sleep apneas. ${ }^{23}$

In diabetic patients, the elevated number of sleep apneas appears to be predominantly of central rather than obstructive origin, likely because of the frequent presence of au- 
tonomic neuropathy in this disease. Poor sleep quality in diabetic patients is related to higher $\mathrm{HbA}_{1 \mathrm{C}}$ values. ${ }^{24}$

\section{OSA and Cardiovascular Diseases}

Mortality is greater in patients having AHI values greater than $20 .{ }^{25,26}$ Obstructive sleep apnea severely affects cardiac function in compromised hearts. The Sleep Heart Health Study showed that cardiovascular diseases (CVD) were more frequent in OSA patients, even in those with moderate AHI values. ${ }^{27}$ In this cross-sectional study performed on more than 6000 subjects, a strong correlation was established between AHI and the prevalence of CVD (coronary heart diseases, heart failure, and stroke). ${ }^{27} \mathrm{Ob}$ structive sleep apnea at baseline is a significant predictor of CVD, and a recent study showed that the CVD incidence was $57 \%$ in untreated vs $7 \%$ in efficiently treated OSA patients. ${ }^{28}$ In addition to hypertension, OSA patients have a $58 \%$ prevalence of cardiac arrhythmias. ${ }^{1}$ Acute experimental OSA leads to arterial stiffness. ${ }^{29}$ Chronic OSA patients accordingly show diminished aortic distensibility and have an increased stiffness index. ${ }^{30}$ Patients with OSA spending $9 \%$ of the night time with $\mathrm{SaO}_{2}$ below $90 \%$ exhibit carotid wall hypertrophy. ${ }^{31}$

\section{OSA, METABOLIC DERANGEMENTS, AND CVD: A BIDIRECTIONAL PROCESS?}

As briefly stated above, the increase in OSA in patients suffering from IR/diabetes or severe cardiac pathologies is a well-known clinical observation. Additionally, OSA is likely to aggravate preexisting diseases. The first clinical studies were biased by confounding factors, mainly the presence of obesity, but also by subjective self-answered questionnaires or self-reporting of snoring. Later studies using more careful patient observations (eg, polysomnography and blood sampling during apneas) and improved matching of patients control groups, as well as experimental investigations, suggested that OSA might induce by itself —or intensify - the switch towards diabetes and lead to macrovascular complications. ${ }^{32}$

\section{Do OSAs Induce Insulin Resistance?}

A main question is whether OSA can be causal to the metabolic- and vascular-related disturbances (Fig.1). In snoring children ${ }^{19}$ and adults, ${ }^{33}$ higher insulin levels are present, usually revealing IR. Fasting insulin levels correlate with OSA. ${ }^{34}$ Nonobese patients suffering from OSA have more visceral fat ${ }^{35}$ and diminished adiponectin, ${ }^{36}$ both major situations favoring IR and vascular disturbances. Pio-

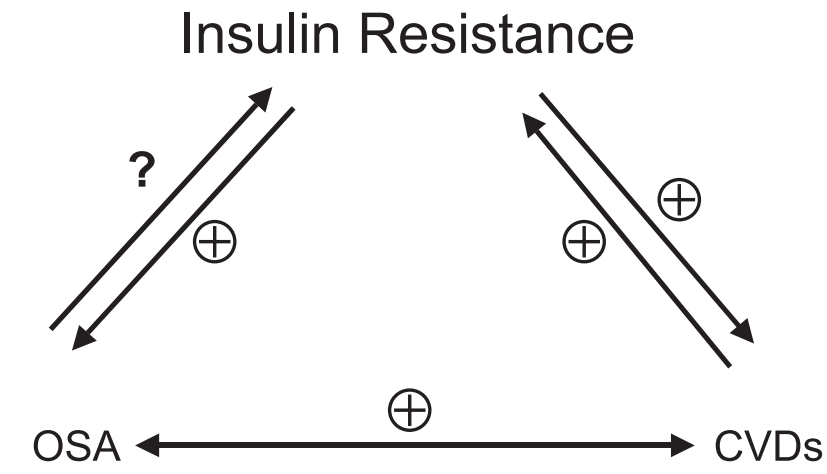

Figure 1 - Scheme illustrating the actual hypothesis of possible bidirectional relationships between obstructive sleep apneas (OSA), insulin resistance, and cardiovascular (CVD) disorders

neering studies have recently suggested that the presence of the ApoEe4 allele might predispose to OSA, and the presence of this genetic variation also in Alzheimer's disease raises the possibility that OSA might, via recurrent hypoxic episodes, be involved in the cognitive deterioration affecting these patients. ${ }^{37}$ Humans exposed to high altitude hypoxia exhibit decreased insulin sensitivity, indicating that hypoxia per se is able to generate IR. ${ }^{38}$ Even acute hypoxia for $30 \mathrm{~min}$ at a $\mathrm{SaO}_{2}<75 \%$ leads to a decrease in glucose disposal rate. ${ }^{39}$ Interestingly, such data are similar to what is observed in hypoglycemia, despite major differences in stress hormone profiles, thus pointing again towards a specific role for hypoxia. Here also, sleep deprivation per se may play a role, since short sleepers have an odds ratio of 2 for developing IR. ${ }^{40}$

In preclinical experiments, the main features of OSA can be simulated by sophisticated technical devices allowing repetitive and abrupt adjustable changes in respiratory gas in chambers. This procedure is called intermittent hypoxia (IH). In vitro, cultured cells can be exposed to selected levels of oxygenation. For example, IH or fructose feeding (another way to induce IR) both reduce the ventilatory response to hypoxia and hypercapnia and lead to elevated insulin concentrations ${ }^{41}$ and reduced insulin sensitivity. ${ }^{38,42}$ Interestingly, IH worsens-while continuous hypoxia improves-glucose tolerance, suggesting that repetitive cycles of low and high oxygen play a determining role. ${ }^{38}$

\section{Do OSAs Favor Diabetes?}

Occasional and regular snoring increases the risk of diabetes by 1.5 and 2.25 respectively..$^{43}$ The incidence of diabetes was doubled over 10 years in middle-aged, habitual snorers. ${ }^{44}$ In a paper that just appeared, a prospective study, the Wisconsin Sleep Cohort, comprising 1387 
patients, evaluated the prevalence and the incidence of type 2 diabetes in subjects with OSA. It appeared that the odds ratio for developing diabetes within 4 years was 1.62 with an AHI > 15, compared with subjects with $\mathrm{AHI}<5$ after adjustments for age, sex, and body habitus. ${ }^{45}$ The prevalence of diabetes in subjects with AHI $>15$ was $14.7 \%$, as compared with $2.8 \%$ in those with $\mathrm{AHI}<5$. Although this study does not constitute a definitive proof, such data strongly argue for a causal role of OSA in diabetes development.

\section{Do OSAs favor Cardiovascular Diseases?}

One of the most striking cardiovascular complications of OSA is hypertension. The sympathetic discharge accompanying hypoxia/reoxygenation induces vascular resistance which does not resume during daytime. ${ }^{1,40}$ Therefore, there is a state of persistent chemoreceptor activation. ${ }^{32}$ The hypertension induced by OSA has a particular profile: diastolic pressure increases early, and patients experience no diurnal variation of systemic blood pressure. Importantly, there is also no nocturnal dipping of blood pressure. This type of hypertension severely affects the brain and heart, with little effect on the kidneys. ${ }^{46}$ Otherwise healthy patients suffering from OSA show increased body weight and sympathetic muscle activity. ${ }^{47}$ Stroke and cardiac arrest in the early morning hours are other typical features of OSA: a lack of normal reaction of brain vessels to isocapnic hypoxia during non-REM sleep could explain the vulnerability of these subjects towards stroke. ${ }^{48}$

In mice, chronic IH increases blood pressure and hematocrit as well as the weights of the left and right ventricle and septum, signs of right heart loading and pulmonary vasoconstriction. ${ }^{49,50}$ The same profile is found in humans: $25 \%$ of OSA patients have mild pulmonary hypertension; $18 \%$ suffer right ventricular dysfunction, and they have a 3 -fold increase in risk for CVD. ${ }^{51}$ The susceptibil- ity of hearts to infarction was increased in rats subjected to 35 days of $\mathrm{IH}^{52}$ Here again, $\mathrm{IH}$ is more detrimental than sustained hypoxia for increasing blood pressure and sympathetic activation. ${ }^{53}$ Obstructive sleep apnea also leads to elevated levels of NPY, another factor of vasoconstriction. ${ }^{54}$ In a study in rats, the $\mathrm{IH}$-induced hypertension was found to last several weeks after cessation of the procedure. ${ }^{55}$ Each additional incident of apnea increased the odds ratio for hypertension by $1 \% .^{56}$ This striking link between OSA and hypertension ${ }^{57}$, as well as that between OSA, congestive heart failure and respiratory alterations ${ }^{58}$ have been widely reviewed recently.

Figure 2 summarizes the main potential consequences of OSAs on metabolic and vascular parameters.

\section{MECHANISMS OF OSA-INDUCED METABOLIC AND VASCULAR DISORDERS}

The similarity of OSA-related pathologies with metabolic syndrome is striking: in addition to hypertension, risk factors for atherosclerosis, inflammation (cytokines), hemostatic disorders, oxidative stress, and defects in vascular reactivity are among the major common features. The following chapter will document the major recent findings in biochemical and cellular mechanisms underlying these complications.

\section{Inflammation / Adhesion Molecules}

As in metabolic syndrome, a mild inflammatory state characterizes OSA. ${ }^{1}$ Indeed, several studies have reported an increase in CRP, IL-6, IL-8, or TNF $\alpha$ in patients with OSA. ${ }^{59-61}$ In adolescents free of CVD but with an AHI > 5, CRP levels were increased even after adjustment for the confounding obesity factor. ${ }^{62}$ Interestingly, partial sleep deprivation also increases CRP levels. ${ }^{63}$ TNF $\alpha$ levels are also elevated in serum and monocytes. ${ }^{60,61,64,65}$ Post apnea,

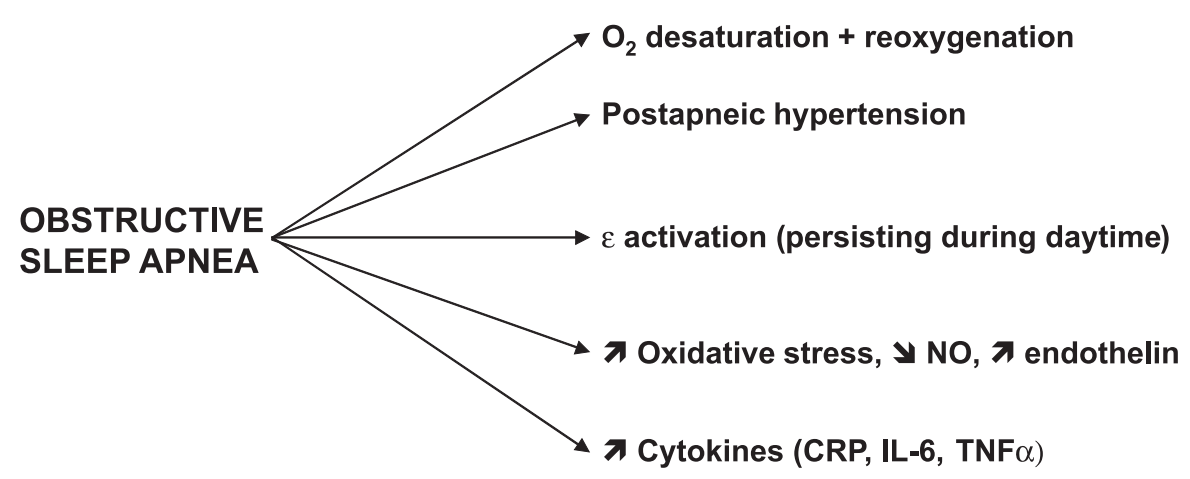

Figure 2 - Main cardiometabolic consequences of obstructive sleep apneas 
TNF $\alpha$ increases immediately after $\mathrm{SaO}_{2}$ reaches a threshold of $85 \% .{ }^{66}$ Moreover, the TNF $\alpha$ circadian rhythm is disturbed (less during night, more during day) ${ }^{67}$ These molecules are known to be closely linked with IR and predictive of type 2 diabetes ${ }^{68}$ Adhesion molecules such as ICAM-1, VCAM-1, or E-selectin are also increased in patients suffering from OSA. ${ }^{1,69}$ A particular role for CD11c and $\mathrm{CD} 15$ has been recently proposed. ${ }^{70}$

\section{Adipokines}

Several studies have demonstrated an increase in circulating leptin levels in OSA patients, which correlates with $\mathrm{SaO}_{2} \cdot{ }^{71}$ Indeed, it has been shown that leptin rises in order to compensate for $\mathrm{IH} .{ }^{38}$ The leptin increase is seen even in otherwise healthy subjects suffering from OSA. ${ }^{47}$ High plasma soluble leptin receptor concentrations and reduced glucose uptake are correlated with OSA, and globally there seems to exist an inverse correlation between insulin sensitivity and leptin receptor concentration. ${ }^{33,72}$ Another substance liberated by fat cells is adiponectin, the role of which is increasingly considered to be protective against IR and vascular disturbances. In OSA patients, in addition to increases in hsCRP and IL-6, adiponectin levels were reduced $^{36}$; however, another study reported the opposite. ${ }^{73}$ This should be taken into account, since leptin is considered important in IR and promotes oxidative stress, another potential factor involved in prediabetes and diabetes (see below). ${ }^{74,75}$

\section{HIF-1 Alpha}

Intermittent hypoxia, even in vitro, increases levels of hypoxia-inducible factor 1 alpha (HIF-1 alpha). ${ }^{76}$ While HIF-1 might first increase as a protective, compensatory mechanism, ${ }^{77}$ its sustained liberation may have deleterious effects $^{77}$ : indeed, HIF-1 is able to reduce eNOS (the endothelial isoform of nitric oxide synthase) and increase iNOS (inducible nitric oxide synthase) and VEGF (vascular endothelial growth factor), with possible consequences to vascular reactivity and permeability. ${ }^{77-80}$

\section{Hemostasis}

Blood platelets are activated and aggregate in OSA. ${ }^{1}$ The blood coagulation system is activated by acute hypoxia. ${ }^{81}$ Type III procollagen, as seen in NASH, correlates with $\mathrm{SaO}_{2}{ }^{71}$ Patients with reduced $\mathrm{SaO}_{2}$ have elevated $\mathrm{D}$ dimer concentrations, indicating defects in the fibrinolytic system. $^{82}$

\section{Lipid Metabolism}

Intermittent hypoxia leads to increased levels of total cholesterol, phospholipids, and triglycerides in normal animals. However, no further aggravation was seen if animals were already hyperlipidemic. ${ }^{83}$ In vitro, $\mathrm{IH}$ also leads to lipid loading of macrophages, a process critical for the development of atherosclerosis. ${ }^{84}$

\section{Vascular Reactivity, Endothelin, Nitric Oxide}

Patients with moderate to severe AHI values show reduced endothelial function and a strong correlation between both parameters ${ }^{85}$ The endothelium-dependent vasodilatation in response to acetylcholine or bradykinin is reduced, while endothelium-independent vasodilatation is unaffected ${ }^{86,87}$ Another study found this defect only in small resistance vessels but not in conduit vessels. ${ }^{88}$ Impaired endothelium-dependent vasodilatation may be due to a defect in nitric oxide (NO) production and/or an excess of vasoconstrictor molecules. In fact, both are seen in OSA: NO production is reduced ${ }^{88,90}$ (Fig. 3), and endothelin 1 (and possibly 2) is increased. In vitro, hypoxia reduces eNOS activity, ${ }^{91}$ and in vivo, basal NO release is decreased in arterioles of rats chronically submitted to $\mathrm{IH} .{ }^{92}$ In addition, plasma levels of ADMA (plasma asymmetric dimethylarginine), an arginine metabolite that interferes with normal arginine uptake, are increased..$^{93}$

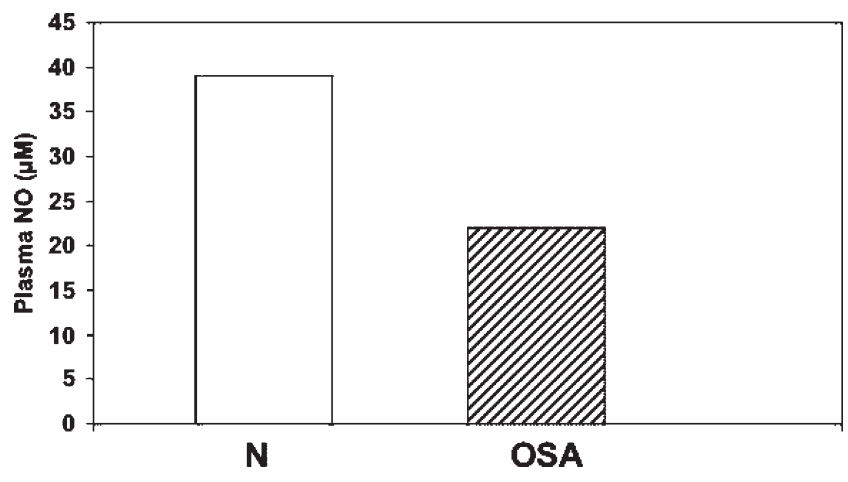

Figure 3 - Reduction in nitric oxide (NO) production in persons with obstructive sleep apnea (OSA) as compared to normal (N) controls (adapted from ref. 89)

As for endothelin, several groups have reported increases in endothelin-1 in sleep deprivation ${ }^{93}$ and OSA. ${ }^{94,95}$ Others have reported increases in big endothelin-1. ${ }^{96,97} \mathrm{In}$ terestingly, experimental IH-induced hypertension showed an oversensitivity in vascular constriction that was selective towards endothelin. ${ }^{98}$ Endothelin is indeed a powerful vasoconstrictor ${ }^{98}$ that may be responsible for $\mathrm{IH}$-induced 
hypertension. ${ }^{99}$ It may also induce oxidative stress by generating superoxide via NADPH oxidase activation. ${ }^{100,101}$ In contrast, one clinical investigation failed to find endothelin1 modifications in patients with OSA. ${ }^{102}$ Thus, despite some remaining controversy, most data points towards an important implication of endothelin in peripheral vascular resistance and hypertension in OSA.

\section{Oxidative Stress}

The occurrence of multiple cycles of hypoxia/ reoxygenation occurring in OSA patients raises the question of oxidative stress as a logical, main cause of the complications found in this pathology. Indeed, both hypoxia per se and, more expectedly, the reoxygenation phase are prone to produce free radicals ${ }^{102}$; in particular superoxide produced by mitochondria during hypoxia acts as an oxygen sensor for adaptive mechanisms to limit the harmfulness of low oxygen. ${ }^{103-109}$ Oxygen species released during hypoxia may act as signalling molecules and have been postulated to resemble a preconditioning stimulus. ${ }^{110}$ It is known from the impressive amount of literature on oxidative stress that this phenomenon is linked to all undesirable side effects associated with OSA. For example, provoking oxidative stress in rats leads to vasoconstriction, to an increase in blood pressure, and a reduction in NO production. ${ }^{111}$ If animals are already insulin-resistant (Zucker rats), administration of a pro-oxidant for some days switches IR to frank diabetes. ${ }^{112}$

Surprisingly, however, the role of oxidative stress in OSA is controversial. Investigations about the occurrence and extent of oxidative stress in OSA have, paradoxically, generated conflicting results. In animals, sleep deprivation reduced glutathione levels in the thalamus and hypothalamus. ${ }^{113}$ Chronic IH led to left ventricular dilatation with increased lipid peroxides and lower superoxide dismutase levels. ${ }^{114}$ The so-called " reductive stress" observed during hypoxia is mediated by NADPH oxidase, the gene and protein expression of which is increased in IH. ${ }^{115}$ Conversely, in mice with no or suppressed capacity to produce NADPH oxidase, no lipid peroxidation or inflammatory reaction could be observed. ${ }^{115}$ However, in humans, data are more controversial; the production of superoxide was increased in neutrophils of OSA patients, ${ }^{116}$ and 8isoprostane was elevated in the breath condensate in a manner correlating with AHI values. ${ }^{117}$ In contrast, several studies failed to document oxidative stress; susceptibility of LDL (low-density lipoprotein) to oxidation, which is an indirect way to detect oxidative stress, was not different from controls. ${ }^{118}$ Another study could detect neither differences in lipid peroxidation nor diminished superoxide dismutase levels. ${ }^{119}$ Very recently, a clinical study dedicated to this topic completely failed to find changes in oxidized LDLs, thiobarbituric acid reactive substances, or isoprostanes, which are different substances that reflect various possible sources/targets of oxidative stress. ${ }^{120}$

Oxidative stress may precede endothelial dysfunction and IR, ${ }^{121}$ which makes it an attractive candidate. However, it seems that in humans, against expectations, there is presently no firm evidence for oxidative stress, at least as a chronic pathological defect. ${ }^{122}$ Considering on one hand the complexity of this field and its numerous contradictions ${ }^{121}$ and, on the other hand, the possibility that local, repetitive, and transient peaks of oxidative stress are not necessarily translated into permanently measurable defects, a definitive conclusion should not be drawn here. Alternative explanations may also exist. For example, early IR primarily occurs in the skeletal muscles, but we ignore whether the insult developing in OSA is sufficient to induce severe abnormalities in this tissue: a recent paper showed that, at least globally, oxygen levels in muscle tissue did not reach critical anaerobic levels during systemic hypoxia close to levels observed in OSA. ${ }^{123}$ Finally, because stress reactions are induced at the gene level, it could be that such mechanisms can compensate for the hypoxic stimulus over long periods of time.

\section{OSA, IR, AND CVD: IS MICROCIRCULATION THE CLUE?}

The similarities between metabolic syndrome (syndrome X) and OSA are striking. If we do not consider the literature about OSA in IR or diabetes but take it from the point of view of OSA as the primary defect, we observe the same profile of disturbances as described for IR and its associated vascular pathologies.

\section{Sympathetic Activation and Its Consequences}

Experimental IH and clinical OSAs lead to elevated sympathetic tone that persists during the daytime. ${ }^{124,125}$ Muscle sympathetic nerve activity and its chemoreflex control are also chronically elevated. ${ }^{126,127}$ Evidently, sympathetic activation will also translate into elevated heart rate and blood pressure as well as left ventricular thickness, eventually leading to cardiac failure. Activation of the central sympathetic nervous system and activation of the hypothalamic-pituitary-adrenal axis, which is also increased in OSA, ${ }^{128}$ are known factors responsible for the development of HT, cortisol elevation, and IR. ${ }^{129}$ Furthermore the sympathetic nervous system controls organs such as the liver and the pancreas, which are closely involved in insu- 
lin and glycemia regulation. ${ }^{130,131}$ In addition, insulin, which increases in OSA, is itself able to stimulate the sympathetic system. Higher levels of heart rate and pulse pressure are responsible for a phenomenon called "hyperdynamic circulation," which is linked to the metabolic syndrome ${ }^{131,132}$ and adverse cardiovascular risks. ${ }^{133,134}$ Interestingly, hyperdynamic circulation occurring in parents predicts IR in their children. ${ }^{135}$

Left ventricular relative wall thickness is inversely correlated with skeletal muscle glucose uptake, both in the presence and absence of hypertension. ${ }^{136}$ Despite normal hormonal signaling in muscles, insulin-stimulated glucose uptake is impaired in patients with chronic heart failure. ${ }^{137}$ Chronic OSA can lead to some degree of heart failure, and this complication, in turn, reduces flow to the hindquarters and limits the vascular flow capacity of mainly high oxidative muscle fibers, ie, those most sensitive to insulin. ${ }^{138}$ Therefore, heart failure reduces the proportion of capillaries supporting continuous whole blood flow. ${ }^{139}$ Interestingly, left ventricular dysfunction without concomitant heart failure may be sufficient to induce disturbances in skeletal muscle arteriolar dimensions and reactivity, suggesting that perturbations in muscle may start very early. ${ }^{140}$

Systemic blood pressure, on the other hand, is accompanied by microvascular rarefaction in skeletal muscle and impaired vasodilatation. ${ }^{141}$ This, in addition to a decrease in type I oxidative muscle fibers and an increase in the diameter of fast-twitch fibers, would increase the diffusion distance for insulin to its sites of action, explaining at least in part how hypertension could be linked to peripheral IR. ${ }^{142-144}$ Indeed, serum cholesterol and glucose are inversely related to the percent of highly insulin-sensitive type I fibers in hypertensive patients, whereas negative correlations were found between the degree of capillarization and glucose, cholesterol, and uric acid. Under conditions of stimulation, the reactivity of skeletal muscle arterioles is limited in hypertensive rats. ${ }^{145,146}$ Impaired endotheliumdependent vasodilatation of small arteries and arterioles is also seen in experimental $\mathrm{IH}^{47,147}$ To what extent these limited reactions of the resistance vessels are responsible for IR in HT is still unclear, but they are clearly related. ${ }^{148,149}$

\section{Microcirculation as a Key Player?}

A somewhat provocative hypothesis should be discussed here: if we consider the group of nervous, chemical, and vascular factors found in OSA, all ingredients are present that favor malfunctioning of the microcirculation. It is interesting to note that the resistance vessels, and not the larger conduit vessels, are the site of impaired endotheliumdependent vasodilatation in OSA. ${ }^{88}$ The question then is if - and how-impaired microcirculation can lead to-and aggravate-the cardiovascular disorders observed in OSA patients.

It has been proposed that microvascular (arterioles, capillaries) defects could precede or act in concert with IR. ${ }^{150,151}$ In skeletal muscle, each capillary supplies several muscle fibers; therefore, one might expect capillary rarefaction, as seen in hypertension or heart failure, to be one of these defects. Moreover, because several (10 to 15) capillaries are grouped into functional units and each unit is controlled by one terminal arteriole, the recruitment of capillaries upon demand depends on the reactivity of the feeding arteriole. Therefore, defects in arteriolar reactivity to nervous inputs or local hemodynamic forces, such as shear stress, may impair the recruitment and/or perfusion of capillaries. Among substances involved in capillary recruitment, insulin itself has hemodynamic properties at the microvascular level; low insulin concentrations that do not increase bulk blood flow dilate terminal arterioles and increase capillary flow. ${ }^{152-154}$ It has been suggested that small increases in insulin from meals, by opening additional microcirculatory units, "open its own way" for reaching skeletal muscle cells in order to store excess postprandial glucose. ${ }^{155}$ Other physiological regulatory processes that are specific for the microcirculation, such as precapillary arteriolar vasomotion, may also be defective and lead to a patchy and inadequate tissue perfusion. ${ }^{156}$ Any defect in these processes leads to reduced functional capillary density and thereby to impaired muscle glucose delivery and uptake, which consequently favors the development of IR.

Although this hypothesis still needs to be fully confirmed, ${ }^{157-159}$ the profile of OSA fits largely with this theory. Today, OSAs can be reasonably well simulated in animals, new devices allow microcirculation to be measured noninvasively in humans, and clinical awareness of the frequency and importance of this pathology is sharply growing. Therefore, targeted microcirculatory investigations should be implemented to evaluate the importance of this anatomical entity.

\section{CONCLUSION / PERSPECTIVES}

The explosion of data within the past 5 years indicates that OSA is a "young" investigated disease, inasmuch as its potential harmfulness is concerned. The classical view of this pathology has largely been modified in recent years by demonstrating that it is a serious medical situation linked with behavioral, anatomical, and physiological disturbances leading to metabolic and cardiovascular complications. Moreover, it appears to be responsible for a non-negligible fraction of car accidents and human deaths as a conse- 
quence of daytime sleepiness.

The development of continuous positive airway pressure (CPAP) as a therapy for OSA has generated mixed results, even if one excludes the limited patient compliance due to discomfort. Thus, while surrogate endpoints such as $\mathrm{AHI}^{5}, \mathrm{TNF} \alpha^{65}$, reactive oxygen species, ${ }^{87,93}$ or endothelial function were improved by CPAP, some global clinical outcomes have not necessarily shown the same benefit. ${ }^{5,160}$ Moreover, for various reasons, a good portion of the general population has mild OSA and, as such, is at risk for CVD but is not amenable to CPAP therapy. It is therefore important to know much more about this widespread and harmful pathology in order to possibly develop alternative therapeutic strategies.

As for most domains, available data in OSA are partly conflicting. This field of investigation is only beginning and needs more experimental models, confirmations of preliminary findings, and target-directed clinical protocols. In the present review, we have tried to give a broad and updated objective state of our actual knowledge to date. Nevertheless, recent data indicates that OSA may not only be a consequence of IR or obesity but might also be causal, making these relationships bidirectional. If true, this would mean that not only could OSA aggravate existing IR and its related vascular abnormalities, but it could also directly induce an array of perturbations favoring — or directly generating — a state much resembling the well-known metabolic syndrome. We believe that, although the amount of sound data is still limited, the convincing nature of this data supports this latter hypothesis. In view of the list of OSA-modified parameters, we also propose a hypothesis according to which microcirculation might play a key role in this pathology.

\section{RESUMO}

Wiernsperger N, Nivoit P, Bouskela E. Apnéia obstrutiva do sono e resistência à insulina: qual o papel da microcirculação? Clinics. 2006;61(3):253-66.

A apnéia obstrutiva do sono é um problema médico cujo reconhecimento tem aumentado. As últimas pesquisas mostrando sua frequiência na população em geral e seu importante papel metabólico, vascular e comportamental aumentou o número e a natureza das investigações revelando, assim, novos aspectos que abrem caminhos para estudos. Embora a apnéia obstrutiva do sono seja um fenômeno bem conheci- do acompanhando diabetes e obesidade, novas descobertas sugerem que esta relação causal pode também ser verdadeira no sentido inverso. Na realidade, a apnéia obstrutiva do sono pode ser o marco inicial ou primário que induz ou agrava uma série de distúrbios vasculares e metabólicos que se aproximam da síndrome metabólica. Esta revisão discutirá mecanismos estabelecidos e potenciais responsáveis por estas mudanças. A apnéia obstrutiva do sono parece realmente juntar todos os elementos necessários para induzir resistência à insulina, hipertensão e possivelmente insuficiência cardíaca. Após análise cuidadosa destas modificações, con- 
siderando que as mesmas são interligadas, propomos que a microcirculação, como ocorre nos casos de síndrome metabólica e diabetes, poderia representar o denominador comum que mediaria a progressão desta patologia. Esta hipótese é discutida em detalhe e deve ser verificada em estudos pré- clínicos e clínicos apropriados que são atualmente possíveis usando técnicas não-invasivas em humanos.

UNITERMOS: Apnéia obstrutiva do sono. Resistência à insulina. Hypoxia. Síndrome metabólica. Microcirculação.

\section{REFERENCES}

1. Wieber SJ. The cardiac consequences of the obstructive sleep apneahypopnea syndrome. Mount Sinai J Med. 2005;72:10-12.

2. Wexler L, Javaheri S. Sleep apnea is linked to heart failure, but does treatment improve outcome? Cleveland Clin J Med. 2005; 72:929-36.

3. Peppard PE, Young T, Palta M, Skatrud J. Prospective study of the association between sleep-disordered breathing and hypertension. New Engl J Med. 2000;342:1378-84.

4. Patel SR. Shared genetic risk factors for obstructive sleep apnea and obesity. J Appl Physiol. 2005;99:1600-6.

5. Caples SM, Wolk R, Somers VK. Influence of cardiac function and failure on sleep-disordered breathing: evidence for a causative role. J Appl Physiol.2005;99:2433-9.

6. Vgontzas AN, Papanicolaou DA, Bixler EO, Hopper K, Lotsikas A, Lin HM, et al. Sleep apnea and daytime sleepiness and fatigue: relation to visceral obesity, insulin resistance, and hypercytokinemia. J Clin Endocrinol Metab. 2000;85:1151-8.

7. Chasens ER, Weaver TE, Umlauf MG. Insulin resistance and obstructive sleep apnea: is increased sympathetic stimulation the link? Biol Res Nurs. 2003;5:87-96.

8. Tasali E, Van Cauter E. Sleep-disordered breathing and the current epidemic of obesity. Consequence or contributing factor? Am J Respir Crit Care Med. 2002;165:562-3.

9. Vgontzas AN, Legro RS, Bixler EO, Grayev A, Kales A, Chrousos GP. Polycystic ovary syndrome is associated with obstructive sleep apnea and daytime sleepiness: role of insulin resistance. J Clin Endcrinol Metab. 2001;86:517-20.

10. Fatti LM, Scacchi M, Mincelli AI, Lavezzi E, Cavagnini F. Prevalence of sleep apnea and lung disease in acromegaly. Pituitary. 2001;4:25962.

11. Blanco-Perez JJ, Blanco-Ramos MA, Zamarron Sanz C, Souto Ferna A, Mato Mato A, Lamela Lopez J. Acromegaly and sleep apnea. Arch Broncopneumol. 2004;40:355-9.
12. Tanne F, Gagnadoux F, Chazouilleres O, Fleury B, Wendum D, Lasnier E, et al. Chronic liver injury during obstructive sleep apnea. Hepatology. 2005;41:1290-6.

13. Wilcox I, McNamara SG, Collins FL, Grunstein RR, Sullivan CE. "Syndrome Z": the interaction of sleep apnea, vascular risk factors and heart disease. Thorax. 1998;53(Suppl.3):S25-8.

14. Kaditis AG, Alexopoulos EI, Damani E, Karadonta I, Kostadima E, Tsolakidou A, et al. Obstructive sleep-disordered breathing and fasting insulin levels in nonobese children. Pediatr Pulmonol. 2005;40:515-23.

15. Lormeau B, Valensi P; Frenkel AL, Guedj F, Paries J, Cosson E et al. Obstructive sleep apnea in overweight subjects and type 2 diabetic patients. Link between oxygen desaturation, insulin resistance and abdominal adiposity. Diabetologia. 2003;46(Suppl.2):A1692.

16. Ip MS, Lam B, Ng MM, lam WK, Tsang KW, Lam KSL. Obstructive sleep apnea is independently associated with insulin resistance. Am J Respir Crit Care Med. 2002;165:670-6.

17. Punjabi NM, Sorkin JD, Katzel LI, Goldberg AP, Schwartz AR, Smith PL. Sleep-disordered breathing and insulin resistance in middle-aged and overweight men. Am J Respir Crit Care Med. 2002;165:677-82.

18. de la Eva RC, Baur LA, Donaghue KC, Waters KA. Metabolic correlates with obstructive sleep apnea in obese subjects. J Pediatr. 2002;140:654-9.

19. Spiegel K, Leproult R, Van Cauter E. Impact of sleep debt on metabolic and endocrine function. Lancet. 1999;354:1435-9.

20. Spiegel K, Knutson K, Leproult R, Tasali E, van Cauter E. Sleep loss: a novel risk factor for insulin resistance and type 2 diabetes. J Appl Physiol. 2005 99:2008-19.

21. Punjabi NM, Shahar E, Redline S, Gottlieb DJ, Givelber R, Resnick HE. Sleep-disordered breathing, glucose intolerance, and insulin resistance: the Sleep Heart Health Study. Am J Epidemiol. 2004;160:521-30. 
22. Meslier N, Gagnadoux F, Giraud P, Person C, Ouksel H, Urban T, et al. Impaired glucose-insulin metabolism in males with obstructive sleep apnea syndrome. Eur Respir J. 2003;22:156-60.

23. Ramadan W, Petitjean M, Loos N, Geloen A, Vardon G, Delanaud S, et al. Effect of high-fat diet and metformin treatment on ventilation and sleep apnea in nonobese rats. Resp Physiol Neurobiol. In press.

24. Sanders MH, Givelber R. Sleep disordered breathing may not be an independent risk factor for diabetes, but diabetes may contribute to the occurrence of periodic breathing in sleep. Sleep Med. 2003;4:349-50.

25. Yaggi HK, Concato J, Kernan WN, Lichtman JH, Brass LM, Mohsenin V. Obstructive sleep apnea as a risk factor for stroke and death. N Engl J Med. 2005;353:2070-3.

26. He J, Kryger MH, Zorick FJ, Conway W, Roth T. Mortality and apnea index in obstructive sleep apnea. Experience in 385 male patients. Chest. 1988;94:9-14.

27. Shahar E, Whitney CW, Redline S, Lee ET, Newman AB, Nieto FJ, et al. Sleep-disordered breathing and cardiovascular disease. Am J Respir Crit Care Med. 2001;163:19-25.

28. Peker Y, Hedner J, Norum J, Ktaiczi H, Carlson J. Increased incidence of cardiovascular disease in middle-aged men with obstructive sleep apnea: a 7-year follow-up. Am J Respir Crit Care Med. 2002;166:159-65.

29. Jelic S, Bartels MN, Mateika JH, Ngai P, DeMeersman RE, Basner RC. Arterial stiffness increases during obstructive sleep apnea. Sleep. 2002;25:850-5.

30. Kasikcioglu HA, Karasulu L, Durgun E, Oflaz H, Kasikcioglu E, Cuhadaroglu C. Aortic elastic properties and left ventricular diastolic dysfunction in patients with obstructive sleep apnea. Heart Vessels. 2005;20:239-44.

31. Baguet JP, Hammer L, Levy P, Pierre H, Launois S, Mallion JM, et al. The severity of oxygen desaturation is predictive of carotid wall thickening and plaque occurrence. Chest. 2005;128:3407-12.

32. Yun AJ, Lee PY, Bazar KA. Autonomic dysregulation as a basis of cardiovascular, endocrine, and inflammatory disturbances associated with obstructive sleep apnea and other conditions of chronic hypoxia, hypercapnia, and acidosis. Med Hypotheses. 2004;62:852-6.

33. Manzella D, Parillo M, Razzino T, Gnasso P, Buonanno S, Gargiulo A, et al. Soluble leptin receptor and insulin resistance as determinant of sleep apnea. Int J Obesity. 202;26:370-5.

34. Strohl KP, Novak RD, Singer W, Cahan C, Boehm KD, Denko CW, et al. Insulin levels blood pressure and sleep apnea. Sleep. 1994;17:6148 .

35. Chin K, Shimizu K, Nakamura $T$ et al. Changes in intraabdominal visceral fat and serum leptin levels in patients with obstructive sleep apnea syndrome following nasal continuous positive pressure therapy. Circulation. 1999; 100:706-712.

36. Teramoto S, Yamamoto H, Yamaguchi Y, Namba R, Ouchi Y. Obstructive sleep apnea causes systemic inflammation and metabolic syndrome. Chest. 2005;127:1074-5.

37. Abrams B. Add Alzheimer's to the list of sleep apnea consequences. Med Hypotheses. 2005;65:1201-2.

38. Polotsky VY, Li J, Punjabi NM, Rubin AE, Smith PL, Schwartz AR, et al. Intermittent hypoxia increases insulin resistance in genetically obese mice. J Physiol. 2003;552:253-64.
39. Oltmanns KM, Gehring H, Rudolf S, Schultes B, Rook S, Schweiger $\mathrm{U}$, et al. Hypoxia causes glucose intolerance in humans. Am J Respir Crit Care Med. 2004;169:1231-7.

40. Boethel CD. Sleep and the endocrine system: new associations to old diseases. Curr Opin Pulm Med. 2002;8:502-5.

41. Schlenker EH, Shi Y, Wipf J, Martin DS, Kost CK. Fructose feeding and intermittent hypoxia affect ventilatory responsiveness to hypoxia and hypercapnia in rats. J Appl Physiol. 2004;97:1387-94.

42. Djovkar A. Influence of intermittent hypoxia on intravenous glucose tolerance and insulin sensitivity in anesthetized normal rats. Horm Metab Res. 1983;15:254-5

43. Al-Delaimy WK, Manson JE, Willett WC, Stampfer MJ, Hu FB Snoring as a risk factor for type II diabetes mellitus: a prospective study. Am J Epidemiol. 2002;155:387-93.

44. Elmasry A, Janson C, Lindberg E, Gislason T, Tageldin MA, Boman G. The role of habitual snoring and obesity in the development of diabetes: a 10-year follow-up study in a male population. J Int Med. 2000;248:13-20.

45. Reichmuth KJ, Austin D, Skatrud JB, Young T. Association of sleep apnea and type II diabetes: a population-based study. Am J Respir Crit Care Med. 2005;172:1590-5.

46. Sharabi Y, Rabin K, Grossman E. Sleep apnea-induced hypertension: mechanisms of vascular changes. Expert Rev Cardiovasc Ther. 2005;3:937-40.

47. Phillips BG, Kato M, Narkiewicz K, Choe I, Somers VK. Increases in leptin levels, sympathetic drive, and weight gain in obstructive sleep apnea. Am J Physiol. 2000;279:H234-7.

48. Meadows GE, O'Driscoll DM, Simonds AK, Morell MJ, Corfield DR. Cerebral blood flow response to isocapnic hypoxia during slow-wave sleep and wakefulness. J Appl Physiol. 2004;97:1343-8.

49. Campen MJ, Shimoda LA, O'Donnell CP. Acute and chronic cardiovascular effects of intermittent hypoxia in C57BL/6J mice. J Appl Physiol. 2005;99:2028-35.

50. Bradford A. Effects of chronic intermittent asphyxia on haematocrit, pulmonary arterial pressure and skeletal muscle structure in rats. Exp Physiol. 2004;89:44-52.

51. Gami AS, Somers VK. Obstructive sleep apnea, metabolic syndrome and cardiovascular outcomes. Eur Heart J. 2004;25:709-11.

52. Lefebvre B, Godin-Ribuot D, Joeux-Faure M, Caron F, Bessard G, Levy $\mathrm{P}$, et al. Functional assessment of vascular reactivity after chronic intermittent hypoxia in the rat. Respir Physiol Neurobiol. 2005; in press

53. Prabhakar NR. Oxygen sensing during intermittent hypoxia: cellular and molecular mechanisms. J Appl Physiol. 2001;90:1986-94.

54. Barcelo A, Barbe F, Llompart E, de la Pena M, Duran-Cantolla J, Ladaria A, et al. Neuropeptide $Y$ and leptin in patients with obstructive sleep apnea syndrome: role of obesity. Amer J Respir Crit Care Med. 2004;171:183-7.

55. Fletcher EC. Effect of episodic hypoxia on sympathetic activity and blood pressure. Respir Physiol. 2000;119:189-97.

56. Lavie P, Herer P, Hoffstein V. Obstructive sleep apnea syndrome as a risk factor for hypertension: population study. BMJ. 2000 320:479-82. 
57. Robinson GV, Stradling JR, Davies RJO. Obstructive apnoea/ hypopnoea syndrome and hypertension. Thorax. 2004;59:1089-94.

58. Lorenzi-Filho G, Genta PR, Figueiredo AC, Inoue D. Cheyne-stokes respiration in patients with congestive heart failure: causes and consequences. Clinics. 2005;60:332-344.

59. Yokoe T, Minoguchi K, Matsuo H, Oda N, Minoguchi H, Yoshino G, et al. Elevated levels of C-reactive protein and interleukin-6 in patients with obstructive sleep apnea syndrome are decreased by nasal continuous positive airway pressure. Circulation. 2003;107:1129-34.

60. Ciftci TU, Kokturk O, Bukan N, Bilgihan A. The relationship between cytokine levels with obesity and obstructive sleep apnea syndrome. Cytokine. 2004;28:87-91

61. Liu H, Liu J, Xiong S, Shen G, Zhang Z, Xu Y. The change of interleukin- 6 and tumor necrosis factor in patients with obstructive sleep apnea syndrome. J Tongji Med Univ. 2000;20:200-2.

62. Larkin EK, Rosen CL, Kirchner HL, Storfer-Isser A, Emancipator JL Johnson N, et al. Variation of C-reactive protein levels in adolescents. Circulation. 2005;111:1978-84

63. Meier-Ewert HK, Ridker PM, Rifai N, Regan MM, Price NJ, Dinges DF, et al. Effect of sleep loss on C-reactive protein, an inflammatory marker of cardiovascular risk. J Am Coll Cardiol. 2004;43:678-83.

64. Minoguchi K, Tazaki T, Yokoe T, Minoguchi H, Watanabe Y, Yamamoto $\mathrm{M}$, et al. Elevated production of tumor necrosis factor alpha by monocytes in patients with obstructive sleep apnea syndrome. Chest. 2004;126:1473-9.

65. Ryan S, Taylor CT, McNicholas WT. Selective activation of inflammatory pathways by intermittent hypoxia in obstructive sleep apnea syndrome. Circulation. 2005; 112:2660-7.

66. Alberti A, Sarchielli P, Gallinella E, Floridi A, Floridi A, Mazzotta G, et al. Plasma cytokine levels in patients with obstructive sleep apnea syndrome: a preliminary study. J Sleep Res. 2003;12:305-11.

67. Entzian P, Linneann K, Schlaak M, Zabel P. Obstructive sleep apnea syndrome and circadian rythms of hormones and cytokines. Am J Respir Crit Care Med. 1996;153:1080-6.

68. Pradhan AD, Manson JE, Rifai N, Buring J, Ridker PM. C-reactive protein, interleukin- 6 and risk of developing type 2 diabetes mellitus. JAMA. 2001;286:327-34.

69. Ohga E, Nagase T, Tomita T, Teramoto S, Matsuse T, Katayama H Increased levels of circulating ICAM-1, VCAM-1, and L-selectin in obstructive sleep apnea syndrome. J Appl Physiol. 1999;87:10-14.

70. Dyugovskaya L, Lavie P, Lavie L. Increased adhesion molecules expression and production of reactive oxygen species in leukocytes of sleep apnea patients. Am J Respir Crit Care Med. 2002;165:934-9.

71. Tatsumi K, Kasahara Y, Kurosu K, Tanabe N, Takiguchi Y, Kuryiama T. Sleep oxygen desaturation and circulating leptin in obstructive sleep apnea-hypopnea syndrome. Chest. 2005;127:716-21.

72. Ogawa T, Hirose H, Yamamoto Y, Nishikai K, Miyashita K, Nakamura $\mathrm{H}$, et al. Relationships between serum soluble leptin receptor level and serum leptin and adiponectin levels, insulin resistance index, lipid profile, and leptin receptor gene polymorphisms in the Japanese population. Metabolism. 2004;53:879-85.
73. Wolk R, Svatikova A, Nelson CA, Gami AS, Govender K, Winnick $\mathrm{M}$, et al. Plasma levels of adiponectin, a novel adipocyte-derived hormone, in sleep apnea. Obes Res. 2005;13:186-90.

74. Bouloumie A, Marumo T, Lafontan M, Busse R. Leptin induces oxidative stress in human endothelial cells. Faseb J. 1999;13:1231-8.

75. Yamagishi S, Edelstein D, Du L, Kaneda Y, Guzman M, Brownlee M Leptin induces mitochondrial superoxide production and monocyte chemoattractant protein-1 expression in aortic endothelial cells by increasing fatty acid oxidation via protein kinase A. J Biol Chem. 2001;276:25096-100

76. Yan G, nanduri J, Bhasker CR, Semenza GL, Prabhakar NR. Calcium/ calmodulin kinase-dependent activation of hypoxia inducible factor1 transcriptional activity in cells subjected to intermittent hypoxia. J Biol Chem. 2005;280:4321-8.

77. Shao G, Gao CY, Lu GW. Alterations of hypoxi-inducible factor 1 alpha in the hippocampus of mice acutely and repeatedly exposed to hypoxia. Neurosignals. 2005;14:255-61.

78. Jurkovicova I, Celec P, Mueska I, Hodosy J. On the origin of cardiovascular complications of sleep apnea syndrome by the mans of molecular interactions. Bratisl Lek Listy. 2003;104:167-73.

79. Natarajan R, Jones DG, Fisher BJ, Wallace TJ, Ghosh S, Fowler J. Hypoxia inducible factor-1: regulation by nitric oxide in posthypoxic microvascular endothelium. Biochem Cell Biol. 2005;83:597-607.

80. Kalaria RN, Spoors L, Laude EA, Emery CJ, Thwaites-Bee D, Fairlie $\mathrm{AE}$, et al. Hypoxia of sleep apnea: cardiopulmonary and cerebral changes after intermittent hypoxia in rats. Respir Physiol Neurobiol. 2004; 140:53-62

81. von Kanel R, Loredo JS, Powell FL, Adler KA, Dimsdale JE. Shortterm isocapnic hypoxia and coagulation activation in patients with sleep apnea. Clin Hemorheol Microcirc. 2005;33:369-77.

82. Shitrit D, Peled N, Shitrit AB, Meidan S, Bendayan D, Sahar G. An association between oxygen desaturation and $\mathrm{D}$-dimer in patients with obstructive sleep apnea syndrome. Thromb Haemost. 2005;94:5447.

83. Li J, Thorne LN, Punjabi NM, Sun CK, Schwartz AR, Smith PL, et al. Intermittent hypoxia induces hyperlipidemia in lean mice. Circ Res. 2005;97:698-706

84. Lattimore JD, Wilcox I, Nakhla S, Langenfeld M, Jessup W, Celermajer DS. Repetitive hypoxia increases lipid loading in human macrophage-a potentially atherogenic effect. Atherosclerosis. 2005; 179:255-9.

85. Itzhaki S, Lavie L, Pillar G, Tal G, Lavie P. Endothelial dysfunction in obstructive sleep apnea measured by peripheral arterial tone response in the finger to reactive hyperemia. Sleep. 2005;28:594-600.

86. Ip MS, Tse HF, Lam BL, tsang KW, Lam WK. Endothelial function in obstructive sleep apnea and response to treatment. Am J Respir Crit Care Med. 2004;169:348-53.

87. Duchna HW, Guillemainault C, Stoohs RA, Orth M, de Zeeuw J, Schultze-Werninghaus G, et al. Das obstructive Schlafapnoe-Syndrom: ein kardiovaskulärer Risikofaktor ? Z. Kardiol. 2001;90:568-75.

88. Kato M, Roberts-Thomson P, Phillips BG, Haynes WG, Winnicki M, Acurso $\mathrm{V}$, et al. Impairment of endothelium-dependent vasodilation of resistance vessels in patients with obstructive sleep apnea. Circulation. 2000;102:2607-10. 
89. Ip MS, Lam B, Chan LY, Zheng L, Tsang KW, Fung PC, et al. Circulating nitric oxide is suppressed in obstructive sleep apnea and is reversed by nasal continuous positive airway pressure. Am J Respir Crit Care Med. 2000;162:2166-71.

90. Schulz R, Schmidt D, Blum A, Lopes-Ribeiro X, Luecke C, Mayer K, et al. Decreased plasma levels of nitric oxide derivatives in obstructive sleep apnea: response to CPAP therapy. Thorax. 2000;55:1046-51.

91. McQuillan LP, Leung GK, Marsden PA, Kostyk SK, Kourembanas S. Hypoxia inhibits expression of eNOS via transcriptional and posttranscriptional mechanisms. Am J Physiol. 1994;267:H1921-7.

92. Tahawi Z, Orolinova N, Johsua IG, bader M, Fletcher EC. Altered vascular reactivity in arterioles of chronic intermittent hypoxic rats. $\mathrm{J}$ Appl Physiol. 2001;90:2007-13.

93. Ohike Y, Kozaki K, Iijima K, Eto M, Kojima T, Ohga E, et al. Amelioration of vascular endothelial dysfunction in obstructive sleep apnea syndrome by nasal continuous positive airway pressure. Circ J. 2005;69:221-26.

94. Palma BD, gabirel A, Bignotto M, Tufik S. Paradoxical sleep deprivation increases plasma endothelin levels. Braz J Med Biol Res. 2002;35:75-9.

95. Saarelainen S, Seppala E, Laasonen K, Hasan J. Circulating endothelin-1 in obstructive sleep apnea. Endothelium. 1997;5:115-8.

96. Jordan W, Reinbacher A, Cohrs S, Grunewald RW, Mayer G, Ruether E, et al. Obstructive sleep apnea: plasma endothelin-1 precursor but not endothelin-1 levels are elevated and decline with nasal continuous positive airway pressure. Peptides. 2005;26:1654-60.

97. Kähler J, Mendel S, Weckmuller J, Orzechowski HD, Mittmann C, Köster R, et al. Oxidative stress increases biosynthesis of big endothelin- 1 by activation of the endothelin- 1 promoter. J Mol Cell cardiol. 2000;32:1429-37.

98. Allahdadi KJ, Walker BR, Kanagy NL. Augmented endothelin vasoconstriction in intermittent hypoxia-induced hypertension. Hypertension. 2005;45:705-9.

99. Hergenroder S, Munter K, Kirchengast M. Effects of endothelin and endothelin receptor antagonism in arteriolar and venular microcirculation. Vasa. 1998;27:216-9.

100. Kanagy NL, Walker BR, Nelin LD. Role of endothelin in intermittent hypoxia-induced hypertension. Hypertension. 2001;37:511-15.

101. Pollock DM, Pollock JS. Endothelin and oxidative stress in the vascular system. Curr Vasc Pharmacol. 2005;3:365-7.

102. Grimpen F, Kanne P, Schulz E, Hagenah G, Hasenfuss G, Andreas S. Endothlein-1 plasma levels are not elevated in patients with obstructive sleep apnea. Eur Respir J. 2000; 15: 320-25.

103. Lavie L. Obstructive sleep apnea syndrome-an oxidative stress disorder. Sleep Med Rev. 2003;7:35-51.

104. Hitka P; Vizek M, Wilhelm J. Hypoxia and reoxygenation increase $\mathrm{H}_{2} \mathrm{O}_{2}$ production in rats. Exp Lung Res. 2003;29:585-92.

105. Pyner S, Coney A, Marshall JM. The role of free radicals in the muscle vasodilatation of systemic hypoxia in the rat. Exp Physiol. 2003;88:733-40.

106. Duranteau J, Chandel NS, Kulisz A, Shao Z, Schumaker PT. Intracellular signalling by reactive oxygen species during hypoxia in cardiomyocytes. J Biol Chem. 1998;273:11619-24.
107. Zuo L, Clanton TL. Reactive oxygen species formation in the transition to hypoxia in skeletal muscle. Am J Physiol Cell Physiol. 2005;289:C207-16.

108. Abe J, Herk BC. Reactive oxygen species as mediators of signal transduction in cardiovascular disease. Trends Cardiovasc Med. 1998;8:59-64

109. Wolin MS, Ahmad M, Gupte A. Oxidant and redox signalling in vascular oxygen sensing mechanisms: basic concepts, current controversies, and potential importance of cytosolic NADPH. Am J Physiol, Lung Cell Mol Physiol. 2005;289:L159-73.

110. Clanton TL, Klawitter PF. Adaptive responses of skeletal muscle to intermittent hypoxia: the known and the unknown. J Appl Physiol. 2001;90:2476-87.

111. Ganafa AA, Socci RR, Eatman D, Silvestrov K, Abukhalaf IK, Bayorh MA. Acute inhibition of glutathione biosynthesis alters endothelial function and blood pressure in rats. Eur J Pharmacol. 2002;454:217-23.

112. Laight DW, Desai KM, Gopaul NK, Anggard EE, Carrier MJ. Prooxidant challenge in vivo provokes the onset of NIDDM in the insulin resistant obese Zucker rat. Br J Pharmacol. 1999;128:269-71.

113. D'Almeida V, Lobo LL, Hipolide DC, de Oliveira AC, Nobrega JN, Tufik S. Sleep deprivation induces brain region-specific decreases in glutathione levels. Neuroreport. 1998;9:2853-6.

114. Chen L, Einbinder E, Zhang Q, Hasday J, Balke CW, Scharf SM Oxidative stress and left ventricular function with chronic intermittent hypoxia in rats. Am J Respir Crit Care Med. 2005;172:915-20.

115. Zhan G, Serrano F, Fenik P, Hsu R, Kong L, Pratico D et al. NADPH oxidase mediates hypersomnolence and brain oxidative injury in a murine model of sleep apnea. Am J Respir Crit Care Med. 2005;172:921-9.

116. Schulz R, Mahmoudi S, Hattar K, Sibelius U, Olschewski H, Mayer $\mathrm{K}$, et al. Enhanced release of superoxide from polymorphonuclear neutrophils in obstructive sleep apnea. Am J Respir Crit Care Med. 2000;162:566-70

117. Carpagnano GE, Khavitonov SA, Resta O, Foschino-Barbaro MP, Gramicioni E, Barnes PJ. Increased 8-isoprostane and interleukin-6 in breath condensate of obstructive sleep apnea patients. Chest. 2002;122:1162-7

118. Wali SO, Bahammam AS, Massaeli,H, Pierce GN, Iliskovic N, Singal $\mathrm{P}$, et al. Susceptibility of LDL to oxidative stress in obstructive sleep apnea. Sleep. 1998;21:290-6.

119. Alzoghaibi MA, Bahammam AS. Lipid peroxides, superoxide dismutase and circulating IL- 8 and GCP-2 in patients with severe obstructive sleep apnea: a pilot study. Sleep breath. 2005;9:119-26.

120. Svatikova A, Wolk R, Lerman LO, Juncos LA, Greene EL, McConnell $\mathrm{JP}$, et al. Oxidative stress in obstructive sleep apnea. Eur Heart J. $2005 ; 24: 2435-9$

121. Gopaul NK, Manraj MD, Hebe A, Yan S, Johnston A, Carrier MJ, et al. Oxidative stress could precede endothelial dysfunction and insulin resistance in Indian Mauritians with impaired glucose metabolism. Diabetologia. 2001;44:706-12.

122. Wiernsperger NF. Oxidative stress as a therapeutic target in diabetes: revisiting the controversy. Diabetes/Metabolism. 2003;29:579-85. 
123. Johnson PC, Vandegriff K, Tsai AG, Intaglietta M. Effect of acute hypoxia on microcirculatory and tissue oxygen levels in rat cremaster muscle. J Appl Physiol. 2005;98:1177-84.

124. Morgan BJ, Crabtree DC, Palta M, Skatrud JB. Combined hypoxia and hypercapnia evokes long-lasting sympathetic activation in humans. J Appl Physiol. 1995;79:205-13.

125. Smith MJ, Muenter NE. Effects of hypoxia on sympathetic neural control in humans. Resp Physiol. 2000;121:163-71.

126. Spaak J, Egri ZJ, Kubo T, Yu E, Ando S, Kaneko Y, et al. Muscle sympathetic nerve acitvity during wakefulness in heart failure patients with and without sleep apnea. Hypertension. 2005;46:1327-32.

127. Cutler MJ, Swift NM, Keller DM, Wasmund WL, Burk JR, Smith ML Periods of intermittent hypoxic apnea can alter chemoreflex contro of sympathetic nerve activity in humans. Am J Physiol, Heart Circ Physiol. 2004;287:H2054-60.

128. Buckley TM, Schatzberg AF. On the interactions of the hypothalamicpituitary-adrenal (HPA) axis and sleep: normal HPA axis activity and circadian rhythm, exemplary sleep disorders. J Clin Endocrinol Metab.2005;90:3106-14

129. Björntorp P, Holm G, Rösmond R. Hypothalamic arousal, insulin resistance and type 2 diabetes mellitus. Diab Med. 1999;16:373-83.

130. Bruce DG, Chisholm DJ, Storlien LH, Kraegegn EW, Smythe GA. The effects of sympathetic nervous system activation and psychological stress on glucose metabolism and blood pressure in subjects with type 2 (non-insulin-dependent) diabetes mellitus. Diabetologia. 1992;35:835-43.

131. Jarhult J, Falck B, Ingemansson S, Nobin A. The functional importance of sympathetic nerves to the liver and endocrine pancreas. Ann Surg. 1979;189:96-100.

132. Stern MP, Morales PA, Haffner SM, Valdez RA. Hyperdynamic circulation and the insulin resistance syndrome ("syndrome "). Hypertension. 1992;20:802-8.

133. Jiang X, Srinivasan SR, Urbina E, Berenson GS. Hyperdynamic circulation and cardiovascular risk in children and adolescents. The Bogalusa Heart Study. Circulation. 1995;91:1101-6.

134. Merritt SL. Sleep-disordered breathing and the association with cardiovascular risk. Prog Cardiovasc Nurs. 2004;19:19-27.

135. Palatini P, Vriz O, Nesbitt S, Amerena J, Majahalme S, Valentini M et al. Parental hyperdynamic circulation predicts insulin resistance in offspring: the Tecumseh Offspring Study. Hypertension. 1999;33:76974.

136. Sundstrom J, Lind L, Valind S, Holmang A, Bjorntorp P, Andren B, et al. Myocardial insulin-mediated glucose uptake and left ventricular geometry. Blood Press. 2001;10:27-32.

137. Kemppainen J, Tsuchida H, Stolen K, Karlsson H, Bjornholm M, Heinonen OJ, et al. Insulin signalling and resistance in patients with chronic heart failure. J Physiol. 2003;550:305-15.

138. McAllister RM, Laughlin MH, Musch TL. Effects of chronic heart failure on skeletal muscle vascular transport capacity of rats. Am J Physiol. 1993;264:H689-91.

139. Richardson TE, Kindig CA, Musch TI, Poole DC. Effects of chronic heart failure on skeletal muscle capillary hemodynamics at rest and during contractions. J Appl Physiol. 2003;95:1055-62.
140. Thomas DP, Hudlicka O, Brown MD, Deveci D. Alterations in small arterioles precede changes in limb skeletal muscle after myocardial infarction. Am J Phsyiol. 1998;275:H1032-9.

141. Salvetti A, Brogi G, DiLegge V, Bernini GP. The inter-relationship between insulin resistance and hypertension. Drugs. 1993;46(Suppl.2):149-59.

142. Egan BM. Neurohumoral, hemodynamic and microvascular changes as mechanisms of insulin resistance in hypertension: a provocative but partial picture. Int J Obes. 1991;15 (Suppl.2):133-9.

143. Saad MF, Rewers M, Selby J, Howard G, Jinagouda S, Fahmi S. Insulin resistance and hypertension: the Insulin Resistance Atherosclerosis Study. Hypertension. 2004;43:1324-31

144. Sauleda J, Garcia-Palmer FJ, Tarraga S, Maimo A, Palou A, Agusti AG. Skeletal muscle changes in patients with obstructive sleep apnea syndrome. Respir Med. 2003;97:804-10.

145. Koller A, Huang A. Shear stress-induced dilation is attenuated in skeletal muscle arterioles of hypertensive rats. Hypertension. $1995 ; 25: 758-63$.

146. Losada L, Torres SH, Hernandez N, Lippo M, Sosa A. Muscle arteriolar and venular reactivity in two models of hypertensive rats. Microvasc Res. 2005;69:142-8.

147. Tahawi Z, Orolinova N, Joshua IG, bader M, Fletcher EC. Altered vascular reactivity in arterioles of chronic intermittent hypoxic rats. J Appl Physiol. 2001;90:2007-13

148. Serne EH, Stehouwer CD, ter Maaten JC, ter Wee PM, Rauwerda JA, Donker AJ, et al. Microvascular fucntion relates to insulin sensitivity and blood pressure in normal subjects. Circulation. 1999;99:896-902

149. Olsen MH, Andersen UB, Wachtell K, Ibsen H, Dige-Petersen H. A possible link between endothelial dysfunction and insulin resistance in hypertension. A LIFE substudy. Losartan Intervention For EndpointReduction in Hypertension. Blood Press. 2000;9:132-9.

150. Clark MG, Barrett EJ, Wallis MG, Vincent MA, Rattigan S. The microvasculature in insulin resistance and type 2 diabetes. Semin Vasc Med. 2002;2:21-31

151. Wiernsperger NF, Bouskela E. Microcirculation in insulin resistance and diabetes: more than just a complication ? Diabetes Metab. 2003;295(suppl.4):S77-S88

152. Bouskela E, Cyrino FZ, Wiernsperger N. Effects of insulin and the combination of insulin plus metformin (Glucophage) on microvascular reactivity in control and diabetic hamsters. Angiology. 1997;48:503-14.

153. 153. Coggins M, Lindner J, Rattigan S, Jahn L, Fasy E, Kaul S et al. Physiologic hyperinsulinemia enhances human skeletal muscle perfusion by capillary recruitment. Diabetes. 2001;50:2682-90.

154. Vincent MA, Clerk LH, Lindner JR, Klibanov AL, Clark MG et al Microvascular recruitment is an early insulin effect that regulates skeletal muscle glucose uptake in vivo. Diabetes. 2004;53:1418-23.

155. Wiernsperger $\mathrm{N}$. Vascular defects in the etiology of peripheral insulin resistance in diabetes. A critical review of hypotheses and facts. Diabetes Metab Rev. 1994;10:287-307.

156. Renaudin C, Michoud E, Rapin J, Lagarde M, Wiernsperger N Hyperglycemia modifies the reaction of microvessels to insulin in rat skeletal muscle. Diabetologia. 1998;41:26-33. 
157. Wiernsperger N. Defects in microvascular haemodynamics during prediabetes contributor or epiphenomenon? Diabetologia. 2000;43:1439-48.

158. Wassermannn DH. Interaction of physiological mechanisms in control of muscle glucose uptake. Clin exp Pharmacol Physiol. 2005;32:31923.
159. Matsumoto Y, Ohno H, Noguchi I, Kikuchi Y, Kurihara T. Disturbance of microcirculation due to unhealthy lifestyle: cause of type 2 diabetes. Med hypotheses. 2005; Epub

160. Smurra M, Philip P, Taillard J, Guilleminault C, Bioulac B, Gin H. CPAP treatment does not affect glucose-insulin metabolism in sleep apneic patients. Sleep Med. 2001;2:207-13. 